\title{
KUIDAS ÕPETADA KÕNESÜNTESAATORILE EMPAATIAT? EMOTSIOONI AUTOMAATSE TUVASTUSE VÕIMALUSTEST EESTIKEELSES KIRJALIKUS LAUSES SISALDUVA INFO PÕHJAL
}

\author{
Ene Vainik
}

Ülevaade. Kõnesünteesi loomulikustamise üheks eelduseks on arvuti võime tunda tekstist ära emotsionaalseid lauseid. Artiklis tutvustatakse eestikeelse kirjutatud teksti automaatse emotsioonituvastaja (AET) loomise taustaks olevaid teoreetilisi seisukohti ja kirjandust, millest võib ülesande lahendamisel abi olla. Seejärel antakse ülevaade inimeste poolt piisava kindlusega ära tuntud emotsioonilausete mitmetest parameetritest ja hinnatakse nende rakendatavust arvuti tulevases emotsioonituvastuses. Osutub, et automaatse emotsioonituvastaja loomisel ei ole võimalik otse üle võtta välismaiseid eeskujusid, kuna emotsioonide väljendamine on mõningal määral kultuurisidus ja nende väljendus kirjalikus tekstis ripub ära konkreetse keele eripärast. Tuvastuseks vajalikud keeleressursid - emotsioonidega seotud eesti keele sõnade ja konstruktsioonide loendid - tuleb AET jaoks algusest peale ise luua.*

Võtmesõnad: emotsioonid, kirjalik tekst, kõnesüntees, tundmusanalüüs, afektirehkendus, eesti keel

\section{Sissejuhatus}

Empaatia tähendab võimet mõista teise inimese tundeid ja emotsioone ning loomulikku inimestevahelist suhtlust me ilma selleta ette ei kujuta (vt nt Goleman 2006). Ka inimese ja arvuti suhtluse arendamine on jõudnud niikaugele, et mingil määral oodatakse arvutiltki inimese emotsioonidega "samal lainel olemist". Nii on näiteks eesti keeletehnoloogia arendamise raames kerkinud ülesanne muuta kõnesüntesaatori poolt (re)produtseeritavate lausungite kõlapilti loomulikumaks,

* Selle artikli valmimisel on tulnud finantstugi kahest allikast: sihtfinantseeritav teema nr SF0050023s09 ja Eesti 
reaalsele inimsuhtlusele lähedasemaks (Altrov, Pajupuu 2007). Muude meetmete (nagu nt hingamispauside, vt Kerge jt 2008) kõrval plaanitakse süntesaatorit õpetada kõnes võimalikult inimlähedaste akustiliste vahenditega väljendama tekstiga kaasnevaid emotsioone.

Selleks, et süntesaatori poolt ette loetud tekst mõjuks võimalikult loomulikuna, peab kõlapilt olema vastavuses teksti autori poolt kogetud emotsiooniga (Iida jt 2003, Ververidis, Kotropoulos 2006). Selle eesmärgi saavutamise juures on kaks olulist lõiku: 1) modelleerida emotsioonide väljendamise kõlalised parameetrid ja 2) õpetada arvutit kirjaliku teksti põhjal aru saama, millist emotsionaalset registrit peaks süntesaator igal antud juhul rakendama. Käesolev artikkel tegeleb neist teisena mainitud ülesande võimalike lahendusteede tutvustamisega ja püüab hinnata nende perspektiivikust eesti keele spetsiifikat arvestades.

Üks on selge - selleks, et arvutit saaks "õpetada" kirjalikus tekstis sisalduvat emotsiooni tuvastama, peame olema veendunud, et emotsioonidel on kirjalikus tekstis tõepoolest mingid märgilised kandjad olemas. Kuni ei ole saanud üldiseks tavaks lisada kirjutatud lausetesse spetsiaalseid emotsioonidele viitavaid märke (nt emotikone $)^{1}$, tuleb eeldada, et emotsiooni tuvastamiseks piisab eestikeelses kirjalikus lauses sisalduvatest muudest kirjamärkidest ja et tavainimesed tulevad emotsiooni tuvastamisega kirjutatud lauses sellele infole tuginedes üldjuhul suuremate probleemideta toime. Kuivõrd need eeldused aga paika peavad, sellest allpool lähemalt.

Artiklis tutvustatakse esmalt taustaks olevaid teoreetilisi seisukohti emotsioonide keeles väljendumisest ning antakse ülevaade kirjandusest, millest võib eesti keele kirjaliku lause emotsioonituvastaja (edaspidi AET) loomisel abi olla. Empiirilises osas esitatakse nn andmekaeve (ingl data mining) tulemused, mille käigus analüüsiti 361 eestikeelset lauset, milles inimesed olid emotsiooni olemasolu või puudumise piisava üksmeelega kindlaks teinud. Andmekaeve eesmärgiks oli välja selgitada kõikvõimalikud emotsioonide tunnuslikud parameetrid kirjutatud tekstilauses ja hinnata nende rakendatavust arvuti tulevases emotsioonituvastuses. Artikli viimases osas vaetakse tulemusi ja arutletakse AET loomise perspektiivide üle.

\section{Kuidas saavad emotsioonid verbaalses suhtluses väljenduda?}

Selleks, et õpetada arvutit emotsioone tekstist ära tundma, peaksime esmalt teadma, kuidas need emotsioonid seal põhimõtteliselt saavad esindatud olla. Kas on üldse enesestmõistetav, et iga lausega kaasneb ilmtingimata emotsioon?

Üldiselt arvatakse, et mingisugune emotsionaalne seisund või meeleolu saadab inimest kogu aeg. Vastavalt sellele, mis oludega tuleb kokku puutuda, kerkivad lühiaegselt esile intensiivsemad reaktsioonid ning nende situatsioonikohast tõlgendamist kogetaksegi emotsioonide ja tunnetena (Damasio 1999). Kui me vaikimisi eeldame, et emotsionaalne foon (oma teatud fluktuatsioonidega) saadab inimest kogu aeg, siis on täiesti loomulik eeldada, et see ei kao ära ka kõneprotsessi ajal, et see toimib keelelise kommunikatsiooniga samaaegselt. Selles mõttes võib tõesti emotsioon saata põhimõtteliselt iga inimliku autoriga lausungit. Samas on selge, et emotsioonide kõnes "kohaloleku" määr varieerub suuresti nii isikuti kui ka eri kultuurides ning žanrides (Wilce 2009, Biber, Finegan 1989). 
Teoreetilises plaanis on emotsioone ja keelelist suhtlemist peetud kuuluvaks interpersonaalse kommunikatsiooni eri liikidesse. Emotsioon on loomult spontaanne, kasutades nn analoogkoodi, ja keel on sümboliline, kasutades digitaalset koodi (Buck 1989, Foolen 1997, Watzlawick jt 1967). Kuivõrd aju-uuringud näitavad kummagi kommunikatsiooniliigiga seotud aktiivsete keskuste paiknemist aju eri osades, on emotsioone ja keelelist suhtlemist peetud teineteisest sõltumatuteks nähtusteks. Teised uurijad väidavad siiski, et emotsioonid ja keel on küll kaks paralleelset suhtlusvahendit, kuid et nad on siiski vastasmõjulised (Reilley, Seibert 2003). See seisukoht sobib kokku ka keeleteaduses traditsiooniliselt juurdunud tõekspidamisega, et keelele on muude funktsioonide kõrval omane ka ekspressiivne funktsioon (Foolen 1997 ja tema viide Bühler 1934).

Kognitiivne lingvist Ad Foolen oletab, et kõnelejate emotsioonid ei väljendu mitte ainult kontseptualiseerituna (referentsiaalses plaanis/ideatsiooniliselt, nt öeldes, et keegi on kurb), vaid et emotsioonidel on kõnes avaldumiseks ka otsetee (1997). See otsetee tähendab seda, et põhimõtteliselt digitaalne ja analoogsõnum põimuvad. Seda seisukohta toetavad valdavalt psühholoogide tööd, milles uuritakse, kuidas inimesed tuvastavad emotsioone kõne prosoodiast lähtuvalt (nt Scherer jt 2008). Kuid emotsioonide ja kõne vastasmõju ei piirdu kindlasti üksnes prosoodiaga. Emotsioonide verbaalse väljendumise otsetee võib tähendada ka seda, et digitaalse koodi (keele) elementide seas leidub selliseidki, mis vahendavad emotsionaalset sõnumit pigem analoogse kodeerimise võtteid kasutades, näiteks ikooniliselt. On näiteks esitatud hüpotees, et afekti või hinnangu väljendamiseks sobivad eelkõige need keelendid, mis väljendavad kogemuse, omaduse või tegevuse intensiivsust ja/või selle kestust ning korduvust (Downes 2000).

Emotsioonide kõnes väljendamine ja nende äratundmine näib olevat midagi baasilist, mis omandatakse varases lapseeas koos keele õppimise ja sotsiaalse kohanemisega. Antropoloogid on leidnud, et afekti verbaalne väljendamine hakkab peale üksiksõna tasandist ja kõik grammatilised vormid positiivse ja negatiivse afekti väljendamiseks omandatakse juba enne viiendat eluaastat (Ochs 1988, viidatud Wilce 2009: 44 kaudu).

Nii lingvistid kui ka antropoloogid on ühel nõul, et emotsioonidel ei ole kõnes mingit neile ainuomast kindlat väljendusviisi - jälgi emotsioonidest võib leida pea kõigil nn traditsioonilistel keeletasanditel (vt Foolen 1997 ja tema viited; Wilce 2009). Eesti keele peale mõeldes: foneetilises plaanis on juba Andrus Saareste (1927) juhtinud tähelepanu häälikute labialiseerimisele beebidega suheldes või siis sõnaalgulise hääliku liigsele aspireerimisele (nn järsk alge) peente prouade erutatud kõnes (nt Khuidas nii?, Vhäega hilus!, See on ju phöörane!). Leksikonis avalduvad emotsioonid näiteks emotsiooninimetustena (nt Vainik 2002), piltlike kirjeldustena (nt Vainik, Velt 2006), vande- ja kirumissõnadena (Voll 2002); emotsionaalsele laetusele osutavad terved sõnaklassid nagu hüüdsõnad või rõhumäärsõnad (Veski 1982). Morfoloogias avaldub emotsionaalne suhtumine nt deminutiivsete ja pejoratiivsete sufiksite, kliitikute kasutamise läbi; süntaksi valda kuulub nt spetsiaalsete lausetüüpide nagu nn kogeja- või eksklamatiivlause olemasolu; toimuda võivad muutused tavapärases sõnajärjes ja infostruktuuris. Ülalloetletuga pole emotsioonide eestikeelses kõnes avaldumise võimaluste ring arvatavasti kaugeltki ammendatud. Mil määral ja kuidas täpselt avalduvad emotsioonid aga eestikeelses kõnes selle kirja pandud, prosoodiast "vabastatud” kujul, vajab samuti alles lähemat uurimist. 


\section{Kas me saame teiste kogemusi üle võtta?}

Kui nn põhiemotsioonid on kultuuriülesed ja universaalsed (Ekman 1982), ning ühised meil koguni teiste imetajatega (Darwin 1998 [1872], viidatud Wilce 2009 vahendusel), siis emotsionaalsete reaktsioonide tõlgendamine ja kogemine on kultuuriliselt mingil määral varieeruv (Wilce 2009) ja annab aluse kategooriate (emotsioonimõistete) loomiseks, mis eri keelte ja kultuuride lõikes sugugi üks-üheselt ei kattu (Kövecses 2006, Wierzbicka 1999). Seetõttu ei saa kindlasti eeldada, et kusagil teisel maal loodud emotsioonituvastaja suudaks tuvastada eestlaste emotsioone. Veel enam, kui eesmärgiks on luua emotsioonituvastaja kirjaliku teksti tunnuste põhjal, siis see on loomulikult seotud konkreetse keelega ja selle kirjaviisiga, mis juba iseenesest välistab teiste keelte ja kultuuride kogemuse automaatse ülevõtmise. Võtta saab aga eeskuju ja seda on kindlasti mõtet teha, kuna emotsioonide kirjutatud keeles väljendumise põhiprintsiibid võivad olla sarnased.

Keeleteaduses on tekstide hinnangulisuse ja afektiga tegeldud peamiselt tekstilingvistika vallas (nt Biber, Finegan 1989, Hunston, Thompson 2001). Rakenduslikku suunda, mille raames tegeldakse meetodite väljatöötamisega selleks, et oleks võimalik automaatselt tuvastada tekstides sisalduvat hoiakut, hinnangut või emotsiooni nimetatakse tundmusanalüüsiks (ingl sentiment analysis). Tehisintellekti loomise paradigma raames tegeldakse sarnaste asjadega ka afektirehkenduse nime all (affective computing) (Picard 1997, Yan jt 2008) ${ }^{2}$. Suuremad edusammud on mõistagi keskustes, kus ülesandele on võimalik pühendada suuremaid ressursse (nii inim-, rahalisi kui juba täies mahus toimivaid keele- ja teadmusressursse). Eelisaasendis on inglise keel, mille suuremahulised märgendatud korpused, tesaurused, WordNet, FrameNet, ConceptNet ja spetsiaalsete afektisõnastike olemasolu loomulikult hõlbustavad uute täppissihitusega rakenduste loomist ja testimist. Ka vene keele puhul teatatakse toimivatest lahendustest ${ }^{3}$. Praeguse seisuga on üldine pilt kirju ning kirjutatud teksti emotsiooni määramise alased uuringud varieeruvad mitmes suhtes, mida alljärgnevalt põgusalt kirjeldatakse.

Esiteks võib tekstiline sisend ehk analüüsi objekt mahult varieeruda. Osa lähenemistest analüüsib ja rehkendab terviktekstide emotsionaalset hoiakut (Shanahan jt 2006, Bracewell jt 2006), osa keskendub lõigule (Iida jt 2003), kõige fokuseeritumad lähenemised üritavad määrata lause, sh isegi osalause emotsiooni (nt Osherenko 2008, Wu jt 2006, Al jt 2007, Wilson jt 2005, Liu jt 2003). Kuivõrd eesti keele kõnesünteesis on akustilise modelleerimise põhiühikuks lause (Mihkla 2007), siis AET loomisel on kasulikumad kogemused just fokuseeritud lähenemistest.

Teiseks varieeruvad lähenemised selles osas, mida õigupoolest soovitakse määrata: kas konkreetset emotsiooni (nt hirm, viha, rõõm, kurbus) või emotsioone üldisemalt iseloomustavaid parameetreid. Esimese lähenemisviisi puhul eeldatakse, et emotsioonid on kategooriana nn loomulik liik (ingl natural kind), mille liikmed erinevad üksteisest situatsioonist ja nimetustest olenemata (Hacking 1999, viidatud Wilce 2009 kaudu). Sellest eeldusest järeldub, et eristatavad peavad olema ka üksikute konkreetsete emotsioonide (nt viha, kurbuse, rõõmu) märgilised väljendused tekstis. Teise lähenemisviisi - nn dimensionaalse emotsioonimudeli puhul ei otsita tekstist mitte niivõrd viiteid konkreetsetele emotsioonidele, kuivõrd keskendutakse emotsioone iseloomustavate üldisemate parameetrite (nagu valents, intensiivsus) tuvastamisele (Obrenovic jt 2005). Rohkem, kauem ja seni suurema

2 Kirjandust tasub ostida ka otsingusõnadega nagu affect sensing, assessing of sentiment ja parsing of affect.

3 Väidetavalt toimiv teksti emotsionaalsuse ja muude psühholoogiliste parameetrite kaardistamise süsteem VAAL 2000 on loodud vene, ukraina ja inglise keele jaoks, vt http://www.vaal.ru/proekt/vaal2000.php (25.02.2010), (vt ka Beljanin 2000: 218). 
eduga on tegutsetud teksti autori üldise hinnangu ja arvamuse polaarsuse (positiivne $v s$. negatiivne) ning intensiivsuse (aktivatsiooni) automaatse tuvastamise alal (nt Osherenko 2008, Osherenko, André 2007, Al jt 2007, Wilson jt 2005). Kui eesmärgiks on seatud konkreetsete emotsioonide tuvastamine, siis on nende arv tavaliselt piiratud vaid nn põhiemotsioonidega (nt Liu jt 2003) või kasutatakse nn vahepealse üldisuseastmega kategooriad (nt õnnelik, õnnetu, neutraalne) (Wu jt 2006, Bracewell jt 2006). On ka mõned lähenemised, mis hõlmavad suuremat emotsioonide ringi ja seovad neid üldiste klassimääratlustega (positiiune, negatiivne, neutraalne) (Grefenstette jt 2006, Bednarek 2008, Mathieu 2006). On autoreid, kes peavad teksti hinnangulisuse määramist ja emotsiooni tuvastamist eri ülesanneteks, mida saab lahendada jupikaupa (Al jt 2007) ning ka autoreid, kes peavad emotsioone hinnangutega lahutamatult seotuks (Bednarek 2009). Selles osas ei ole eesti keele loodava emotsioonituvastaja puhul erilist valikut - AET peab olema suuteline tuvastama konkreetseid emotsioone (esialgu tundma teksti põhjal ära kurbust, viha, rõõmu ja neutraalsust). Seda seetõttu, et eesti kõne emotsionaalsete aspektide akustilise modelleerimise ja sünteesimise aluseks on võetud just kategoriaalne ja mitte dimensionaalne emotsioonimudel ning sellele vastavalt on loodud ka emotsionaalse kõne korpus (vt Altrov 2008).

Lähenemised erinevad ka selles suhtes, kas eesmärgiks seatakse nn kõne autori emotsiooni/hinnangu tuvastamine (nt Biber, Finegan 1989, Hunston,Thompson 2001) või üritatakse tekstist leida vihjed emotsioonidest referentsiaalse kõnelemise kohta, mis võib olla ka nn mitte-autori emotsioon (nt Bednarek 2008). Näiteks hüüatused ja hüüdlaused, samuti piltlik keelekasutus seostuvad kahtlemata keele ekspressiivse funktsiooniga (Foolen 1997), mispuhul emotsiooni pigem väljendatakse kui kirjeldatakse. Seevastu otseste emotsiooni- ja tundenimetuste (nagu rõõm, viha, kurbus, nördimus, kadedus jne) kasutamine (eriti kellegi teise) emotsioonide reflekteerimiseks kujutab endast põhimõtteliselt teistsugust tegevust ja seda seostatakse keele deskriptiivse funktsiooniga ${ }^{4}$. Kuigi nii mõnedki emotsioonituvastuse süsteemid ennast selle eristusega ei vaeva, oleks eesti keele süntesaatori otstarvet silmas pidades ilmselt oluline aru saada, millal lause otseselt väljendab mingit emotsiooni (ja järelikult tuleb mõnd spetsiifilist akustilist registrit rakendada) ja millal lause täiesti emotsioonivabalt kirjeldab või mainib kellegi kolmanda isiku emotsiooni (mispuhul eri registrit rakendada poleks tarvis). Lauset Oh, sa reo! (ekspressiivne lausung) võiks süntesaator ju öelda tunderõhuliselt, kuid deskriptiivset lausungit Naabrimees oli eile väga vihane ja karjus oma naise peale poleks süntesaatoril vaja karjuda, kuigi see sisaldab endas otseseid vihjeid emotsioonile (vihane, karjus).

Julgelt võib öelda, et enamik lähenemisi kasutab emotsiooni/hinnangu tuvastamiseks tekstist leitavaid leksikaalseid tunnuseid. Kasutatakse nn emotsionaalseid võtmesõnu (ingl emotional keywords ) või nn leksikaalset külgetõmbavust (lexical affinity), mis teatud lekseemidel, nagu nt vähk või majanduskrïs, emotsioonide suhtes on (vt ülevaadet ja kriitikat Wu jt 2006: 166, Liu jt 2003: 126). Selleks kasutatakse kas juba olemasolevaid afektisõnastikke (nt Whissell 1989, viidatud Osherenko 2007 vahendusel), kirjeldatakse nende loomist (nt Grefenstette jt 2006, Mathieu 2006) või üritatakse kasutada ka üldotstarbelistes sõnastikes sisalduvat infot (Osherenko 2007). Mõningal juhul kombineeritakse otsest emotsioonisõnavara nn lokaalse grammatikaga, mis tähendab teatud kinnistunud leksikaal-

4 Hea ülevaate selle dihhotoomia esile toomisest eri autorite poolt leiab allikast (Bednarek 2008: 10). 
grammatiliste mallidega arvestamist (Hunston, Sinclair 2001, Bednarek 2008). On tehtud katseid tuvastada emotsiooni mitte ainult otsese, vaid ka piltliku, metafoorse keelekasutuse põhjal (nt Zhang 2008, 2009). Kriitikana leksikaalse lähenemise vastu on välja toodud, et mitte kõik leksikast lähtuvad süsteemid ei ole lause tasandil afekti kalkuleerimise puhul võimelised arvestatama eituse valentsi muutva mõjuga (Liu jt 2003). Näiteks võib süsteem lause Täna polnud just õnnelikem päev minu elus ainult eksplitsiitse emotsioonisõnaga õnnelikem arvestades selle eksikombel "õnnelikuks" klassifitseerida. Teiseks ei tunne üksnes leksikonile toetuvad süsteemid emotsiooni ära nn "ridade vahelt", juhul kui lauses puudub otsene emotsioonile viitav lekseem (nt jääb tuvastamata nördimus lause Vanemad tulevad ööseks koju üksnes magama puhul). Sellel põhjusel on katsetatud ka süsteeme, mis arvestavad emotsiooni määramisel üldiste maailmateadmistega, toetudes selleks suurtele kodifitseeritud teadmusbaasidele nagu ConceptNet ja Open Mind Commonsense (Liu jt 2003).

Loodav AET hakkab ka kindlasti arvestama leksikaalse tasandi infoga, samuti peab ta olema valmis toime tulema eitavast kõnest sugeneva võimaliku tähendusmuutusega lause tasandil. Selleks läheb tarvis ühest küljest toetavat keeleressurssi - emotsioonituvastuses relevantsete sõnade loendit, ning teiseks algoritmi, mis arvestuslike emotsionaalsete "väärtuste" koosmõju lause tasandil kalkuleeriks. Eesti keele aglutineeriv-flekteerivat tüpoloogilist eripära arvestades võib osutuda otstarbekaks ka morfoloogiliste tunnuste ja lõppude koosesinemise mustritega arvestamine. Raskeks läheb kahtlemata arvutile "üldiste maailmateadmiste" õpetamine, mille põhjal ta saaks teha järeldusi emotsioonide kohta lausetes, kus neid otse mainitud ei ole.

\section{Mida saaks arvuti õppida inimestelt?}

Järgnevalt kirjeldan andmekaeve tulemusi, mis on saadud katsetest, kus eesti keelt emakeelena oskavad inimesed on lausete emotsioone üksnes lause kirjapildi põhjal määranud. Eesti keele emotsionaalse kõne korpuse ${ }^{5}$ loomise raames on välja otsitud sobiva pikkusega emotsionaalsed tekstilõigud (loe täpsemalt Altrov 2008), tükeldatud need lauseteks, lausete ja lõikude järjekord tahtsi segi aetud ning lastud katseisikutel otsustada iga lause puhul n-ö kontekstivabalt, kas lausega kaasnev emotsioon on kurbus, viha, rõõm, neutraalne või ei oska öelda. Selliseid teste, kus tuli lause emotsiooni üle otsustada ilma heli kuulmata, oli kokku kuus. Andmete analüüsi algusajaks (25.03.09) oli iga testi sooritanud keskmiselt 18,2 inimest. Testide sooritajaid oli kokku 55 (31 naist ja 24 meest, keskmine vanus 33,3 aastat, STDEV 11,51). Mõni inimene osales ka mitmes testis, kuid mitte keegi neist ei osalenud sama korpuse kuulamiskatsetes. 


\subsection{Emotsiooni äratundmine üksiku lause põhjal}

Kõigepealt peab ütlema, et üksnes kirjalikul kujul ja ilma kontekstita esitatud lausete puhul ei olnud katseisikutel ilmselt sugugi lihtne emotsiooni või selle puudumist (neutraalne) määrata. Seda näitab määrangute suhteliselt suur hajuvus. Tabelist 1 nähtub, et kokku ainult 15 lause puhul oli kõikidel katseisikutel täiesti üksmeelne arvamus selle kategoriseerimise kohta. See moodustab kõigest 2,61\% nendest 574 lausest, mida inimestel lasti hinnata. Samas peab ütlema, et lauseid, mida kõik oleks üksmeelselt emotsioonide suhtes määramatuks pidanud, ei olnud sootuks iga lause kohta oli võimalik võtta vähemalt seisukoht, kas see on neutraalne või sisaldab mingit emotsiooni. Selline tulemus näib kõnelevat sellest, et iga lause võib potentsiaalselt mingi emotsiooniga seostuda, kuid et tugevaid ja seega hästi äratuntavaid emotsioone kogetakse (ja väljendatakse keeleliselt) suhteliselt harva. Teisest küljest näitab selline tulemus, et kirjalikus tekstis ei pruugi olla sugugi piisavalt märgilist informatsiooni emotsioonide tõsikindlaks tuvastamiseks. Viimane järeldus ei ole AET loomise eesmärki silmas pidades just kuigi lootustandev. Jääb ka kolmas võimalus, et informatsioon emotsioonide kohta on siiski lausetes olemas, kuid katseisikud mingil põhjusel ei suuda seda kasutada, näiteks nende isikliku madala empaatia tõttu ${ }^{6}$. Igatahes saab teha järelduse, et kui ka lõigu tasandil on emotsioon üldiselt tuvastatav (Iida jt 2003), siis mitte iga lause neis lõikudes pole eraldivõetuna võrdse väljendusjõuga.

Laused saab paigutada kontiinumile nende emotsionaalse väljendusjõu selguse järgi, mida näitab hinnangute üksmeele määr. Kõige üksmeelsemalt (100\%) tunti viha ära näiteks järgmistes lausetes: Ei saa nï, et töökoht tuhnib su eraelus! Igasugustel peksta ma ennast ka ei lase! Praegune tants alkoholipiïrangute ümber muutub juba labaseks ja naeruväärseks tsirkuseks! Kurbus tunti üksmeelselt ära näiteks järgmistes lausetes: Ma ei tea, kuidas edasi... Mul ei ole enam kodu. Tean, et tal on tööl jamad, kuid ikka jääb tunne, et äkki olen mina süüdi või et ta tahab meie juurest ära minna... Rõõmsaks peeti üksmeelselt lauset: Fantastiline staadion ja fantastiline publik! Neutraalsus väljendus kõige selgemini lausetes: Ma ei tunne Kadri Kukke isiklikult ja Seitsekümmend krooni, palun. Kontiinumi teises otsas on laused, mille osas katseisikud kõige rohkem kahtlesid, näiteks Siis on see ilus kannatus (kas rõõm või neutraalsus?), Eh, sõbrad, nii see ikka ei käi! (viha või neutraalsus?) ja Korraldus on ikka väga "kõva" (rõõm või viha?). Iseloomulik on, et need laused sisaldavad vastuolulist infot. Tõenäoliselt kujuneb ambivalentsete tunnete nagu nostalgia, kahjurõõmu, iroonia jm mitmeplaaniliste tundmuste tuvastamine pähkliks ka arvutile.

Tabel 1. Erineva üksmeelsuse määraga ära tuntud emotsioonid

\begin{tabular}{|l|c|c|c|}
\hline & $\mathbf{1 0 0} \%$ & $\mathbf{7 5 \%}$ & $\mathbf{5 0 \%}$ \\
\hline viha & 7 & 69 & 178 \\
\hline kurbus & 5 & 34 & 87 \\
\hline neutraalne & 2 & 16 & 80 \\
\hline rõõm & 1 & 51 & 86 \\
\hline ei oska öelda & 0 & 0 & 4 \\
\hline Kokku & $\mathbf{1 5 =} \mathbf{2 , 6 1 \%}$ & $\mathbf{1 7 0 =} \mathbf{2 9 , 6 2} \%$ & $\mathbf{4 3 5 = 7 5 , 7 8 \%}$ \\
\hline
\end{tabular}

6 55-st katseisikust sooritasid empaatiat mõõtva testi 20 ja said seal keskmiselt täiesti normikohase empaatiamäära: 


\subsection{Võimalikke tunnuseid, mis aitavad emotsioone ja neutraalsust lauses eristada}

Viisteist 100-protsendilise kindlusega määratud lauset on väga vähe selleks, et selgitada, millised märgilised tunnused võiksid arvutil aidata emotsioone kirjalikus tekstis ära tunda. Seetõttu on edasises sõnavara ja muude karakteristikute analüüsis võetud arvesse laused, mille puhul vähemalt 51\% vastanutest on määranud emotsiooni/neutraalsuse ühtemoodi. Laused, mida pole osatud määrata, on jäetud välja; välja on jäetud ka eri testides kordunud laused (kokku 78). Arvesse tulevate lausete arv on 361 ja see moodustab $63 \%$ katses testitud lausetest. Uuritavate hulgas on 129 viha lauset, 84 rõõmulauset, 76 kurbuselauset ja 72 neutraalset lauset. Kuna eri emotsioonidega lausete arv ei ole võrdne, on järgnevas analüüsis karakteristikud andmete võrreldavuse mõttes normeeritud (arv 100 lause kohta). Et lisaks leksikale võib olla informatiivne ka nt emotsionaalsete lausete suhteline lühidus (Saareste 1927), lauselõpumärk (Laur 1987), sõnaliigiline koosseis vm tunnused mistahes keeletasanditelt, siis vaadeldaksegi järgnevas nn andmekaeve korras mitmesuguste tunnuste distributsiooni emotsiooniti võrreldes samade tunnuste esinemisega neutraalsetes lausetes.

Lõpumärgistus on üks käegakatsutavamaid asju, mis näib mingil määral peegeldavat lause emotsiooni. Umbes kolmandik lausetest (115) sisaldas mõnd tavapärasest punktist erinevat lõpumärki - kas hüüumärki, küsimärki, hüüu-ja küsimärgi kombinatsiooni või kolme punkti. Tabelis 2 on näidatud, kuidas eri emotsiooniga laused lõpumärgistuse alusel eristuvad neutraalsest lausest, mis kaldub valdavalt lõppema punktiga. AET-i jaoks võiks sõnastada tendentsi: kui lause sisaldab hüüu- või küsimärki või kolme punkti, on emotsiooni tõenäosus suur. Küsi- ja hüüumärk (nii eraldi kui kombinatsioonis) ennustavad viha võimalust, üksik hüüumärk rõõmu võimalust ning kolm punkti kurbuse võimalust. See tulemus on hästi kooskõlas Mall Lauri uurimusega, kes leidis samuti, et nii hüüu- kui küsimärk ennustavad suure tõenäosusega mitmesuguseid aktiivseid emotsioone ja punkt seostub kas neutraalsuse või kurbusega (1987). Samas ei saa unustada, et praeguses uurimuses ligi kaks kolmandikku lausetest lõppes punktiga ja nendest vaid umbes kolmandik (28\%) olid hinnatud tõesti neutraalseks. Ülejäänute osas oli kõigi kolme emotsiooni (viha, rõõm, kurbus) osakaal võrdne. Järelikult ei saa AET lauselõpu punkti põhjal veel selle neutraalsust järeldada ja lahti jääb võimalus, et tegemist võib siiski olla emotsionaalse lausega.

Tabel 2. Lauselõpumärkide distributsioon emotsiooniti (arv 100 lause kohta)

\begin{tabular}{|l|c|c|c|c|}
\hline & neutraalne & rõõm & kurbus & viha \\
\hline küsimärk & 2,78 & & 1,32 & 10,08 \\
\hline hüüumärk & & 34,52 & 7,89 & 28,68 \\
\hline kolm punkti & & 13,16 & 0,78 \\
\hline küsi- ja hüüumärk & & & 2,63 & 8,53 \\
\hline punkt & 97,2 & 65,5 & 73,68 & 50,4 \\
\hline
\end{tabular}

7 Nende märkide esinemust ei vaadatud mitte ainult lause absoluutses lõpus, vaid ka näiteks lausesse sisestatud otsese kõne jm juhtudel. 
Eitav kõne on samuti tunnus, mis võiks oluline olla. Näib loogiline arvata, et negatsioon on seotud negatiivsusega mitte üksnes lause sisus, vaid ka tundetoonis. Kui vaadata adverbide ei ja mitte ning verbi olema vormide pole, polegi, polnud esinemust uuritavas materjalis, siis selgus, et kõige rohkem seostuvad nad kurbusega. Üle poole 100 kurbuselausest $(57,8)$ sisaldas mõnda neist sõnadest. Neutraalsetest lausetest oli eitav kolmandik (33,3\%) ja vihalausetest 40\%. Rõõmsatest lausetest sisaldas neid sõnu aga vaid $15,48 \%$. Seega osutubki, et eitavat kõnet on rohkem lausetes, milles tunti ära negatiivsed emotsioonid (viha, kurbus). Positiivsete emotsioonidega (rõõm) laused pole küll kõik jaatavas kõnes, kuid enamikul juhtudest (84\%) on see nii. Valdavalt on jaatavas kõnes ka neutraalsed laused $(66,6 \%)$. Sellised statistilised tendentsid iseloomustavad emotsioonilauseid üldiselt ja ei ole eraldi võetuna kindlasti rakendatavad ühe konkreetse lause üle otsustamisel. AET jaoks võiks siiski sõnastada tendentsi: eitava kõne olemasolul on suurem negatiivsete emotsioonide tõenäosus.

Lause pikkus on järgmine asi, mille poolest emotsionaalsed laused võiks neutraalsest eristuda. Saareste on emotsionaalsete lausete puhul maininud nende tunnusena lühidust ja alistuvate kõrvallausete puudumist (1927). Materjali analüüs osutab, et sellesuunalist tendentsi neutraalsete lausete keskmise pikkuse (9,64 sõnet) ja emotsionaalsete lausete keskmiste pikkuste vahel polnud võimalik tuvastada (rõõm 11,3; viha, 11,2; kurbus 9,8). Emotsionaalsed laused olid neutraalsetest keskmiselt isegi veidi pikemad. Lause keskmine pikkus sõnedes ei ole kindlasti mingi kriteerium AET-le, kuna keskmise sisse mahub pikkuse varieerumine väga suurtes piirides (alates ühesõnelistest lausungitest, nagu Absurd!, Aitab!, Miks?, kuni 23-sõnelise pikima lauseni antud valimis). Kõige rohkem varieerub rõõmsa lause pikkus (STDev 5,18 sõnet). Kui lausete pikkust mõõta aga tähekohtades, siis torkab silma, et kurbuselaused on teistest emotsioonidest (viha, rõõm) keskmisel tervelt 15,5 tähekohta lühemad, järelikult iseloomustab neid koosnemine suhteliselt lühematest sõnedest. Keskmine sõne pikkus kurbuse lauses ongi teistest lühem 4,83 tähemärki (kõigis teistes lausetüüpides stabiilselt 5,5). Siit võiks vahest küll AET jaoks sõnastada tendentsi: kui lauses on suhteliselt rohkem lühikesi sõnesid (kuni 4 tähemärki), siis on põhjust kahtlustada kurbust.

Lause esimese sõna liik on veel selline pisut pealiskaudsem tunnus, mille järgi arvutil võiks olla lihtne orienteeruda. Ligikaudu neljandik uuritud lausetest (26\%) algas mingit sorti asesõnaga, 19\% määrsõnaga, 18\% nimisõnaga, 17\% tegusõnaga, $11 \%$ sidesõnaga ning $2 \%$ hüüdsõnaga. Joonisel 1 esitatud radiaaldiagramm näitab lausete esimeste sõnade sõnaliigilist kuuluvust emotsiooniti võrrelduna neutraalse lausega. Osutub, et tegusõna lause alustajana ei ole kuigi informatiivne, küll aga näiteks määrsõna. Määrsõnaga algaval lausel on suurem tõenäosus olla viha lause ja suhteliselt väiksem tõenäosus olla rõõmu lause. Asesõna lause alguses ennustab kõige rohkem kurbust (eriti kui see on 1. isiku asesõna) ja kõige vähem viha. Omadussõna lause alustajana esineb mingil määral vaid rõõmu lausetes. Sidesõna esineb lause alguses pigem emotsionaalsetel kui neutraalsetel lausetel. Olgu osutatud, et tendentsid on küll olemas, kuid kindlasti pole need kindlad reeglid. On ilmne, et lause esimese sõna liigiline kuuluvus võib olla abistavaks, kuid kindlasti mitte otsustavaks kriteeriumiks emotsioonide $v s$. neutraalsuse tuvastamisel. 


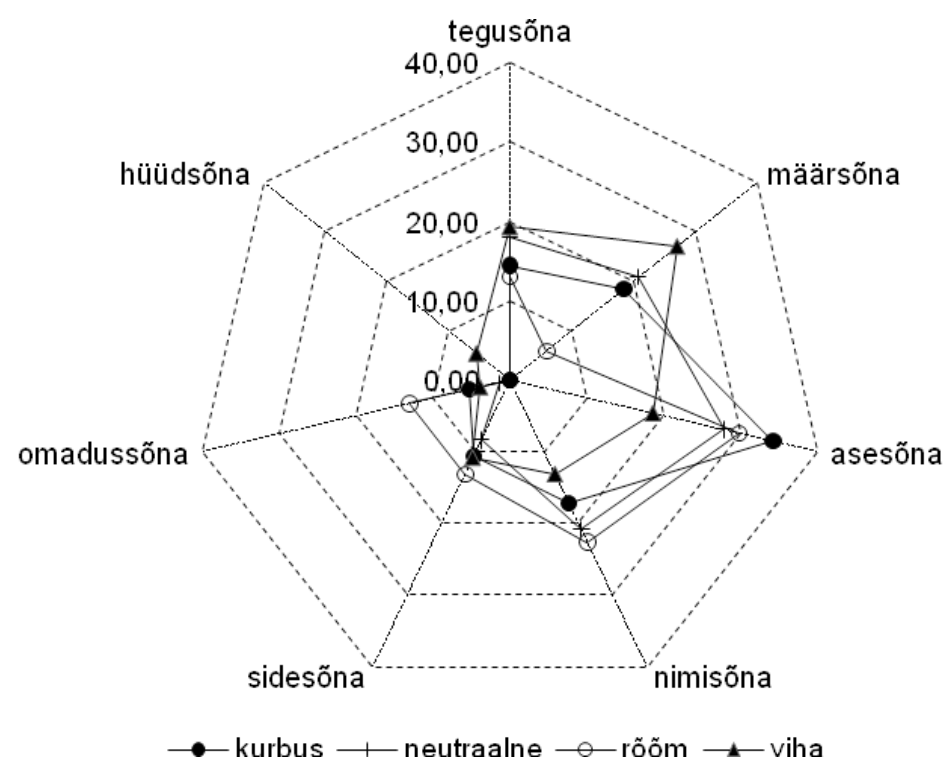

Joonis 1. Lause esisõnade liigiline distributsioon

Kõikide lauses sisalduvate sõnade liigi määramine on kahtlemata juba ressursimahukam tegevus. Kui eeldada, et neutraalses lauses on sõnade liigiline jaotumus optimaalne, siis silma torkavad mõned iseloomulikud kõrvalekalded sellest. Nii kurbuse kui ka viha lausetes esineb rohkem määrsõnu (mõlemas keskmiselt 200) kui neutraalsetes ( $c a 160$ ), seevastu rõõmulausetes on määrsõnu neutraalsest vähem (keskmiselt 116). Adverbide märksa väiksem esinemus rõõmu lausetes võib osaliselt seletuda eelpool sedastatud tendentsiga, et nad on valdavalt jaatavas kõnes (s.t ei sisalda sagedasi adverbe ei ja mitte). Kui kõigis teistes lausetüüpides on nimisõnu keskmiselt pisut üle 200, siis kurbuse lausetes vähem (159).

AET jaoks võiks sõnastada tendentsi: kui lauses on kaks või rohkem adverbi, tuleks kahtlustada viha või kurbust. Kui adverbe on lauses üks või vähem, siis on tõenäolisem neutraalsuse või rõõmu võimalus. Teine tendents oleks: kui lauses on nimisõnu üks või vähem, on suurem kurbuse võimalus.

Mitmesuguste morfoloogiliste markerite ${ }^{8}$ iseloomulik distributsioon tuleb samuti kõne alla ühe võimaliku kriteeriumina, mis võiks arvutil aidata erineva emotsiooniga lauseid ära tunda. Mõnevõrra üllatuslikuna tuli välja, et kõikides analüüsitud lausetüüpides oli eristatavate morfoloogiliste markeritega sõnavormide arvu suhe ilma markeriteta sõnavormide arvu $2: 3$. See tähendab, et lauses iga tunnust või lõppu omava sõna kohta tuleb poolteist sõna, mis on kas muutumatud või o-morfeemiga. Kurbuselausetes ilmnes pisut suurem tendents kasutada markerita sõnu, mis on üheks seletuseks eelpool sedastatud tõsiasjale, et kurbuse laused olid teistest mõnevõrra lühemad mitte niivõrd sõnede kui tähekohtade arvu poolest.

Kui eeldada, et neutraalsetes lausetes on kõikvõimalikke markereid optimaalselt, siis torkab silma mõningate markerite suhteline vähesus või rohkus emotsioonidega lausetes. Joonis 3 kujutab suuremaid esiletuleku erinevusi näidanud markerite distributsiooni. Silma torkab markeri $-d$ suur esinemus rõõmu ja viha lausetes ja vähesem esinemus kurbuse lausetes. Valdavalt on tegemist mitmuse nominatiivi tunnusega ja jääb mulje, et mingil määral selle kasutamine korreleerub tundeelamuse aktiivsuse või intensiivsusega.

8 Laused analüüsiti Filosofti morfanalüsaatoriga ja ühestati käsitsi. Markeriteks nimetatakse siin analüsaatori poolt eristatavaid tunnuseid ja lõppe. 


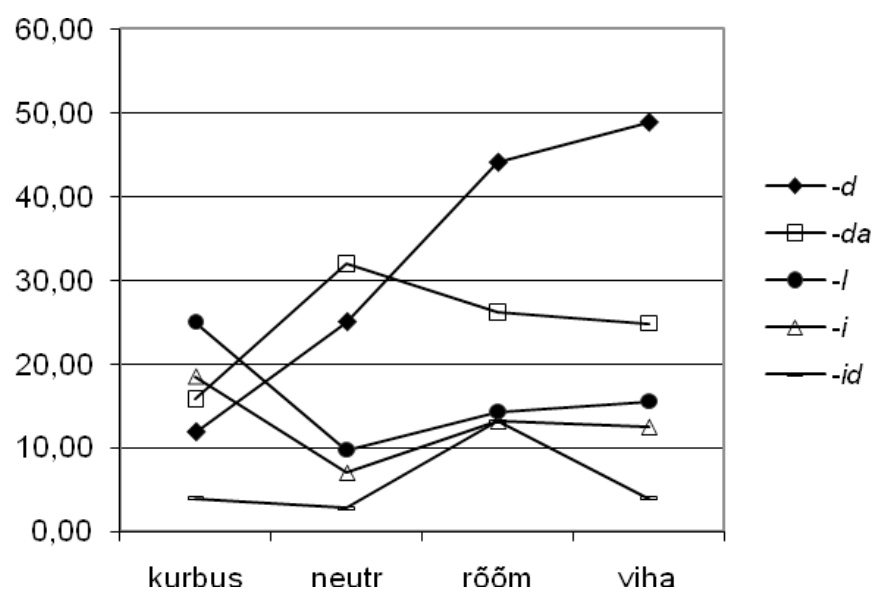

Joonis 3. Morfoloogiliste markerite jaotumus emotsiooniti (arv 100 lause kohta)

Selline tulemus on kooskõlas teoreetilises osas esitletud hüpoteesiga, et afekti või hinnangu väljendamiseks sobivad need keeleelemendid, mis väljendavad kogemuse omaduse või tegevuse intensiivsust ja/või selle kestust, korduvust (Downes 2000). Veel torkab silma, et kurbuse lausetes on kõiki markereid võrreldes neutraalsega vähem, välja arvatud $-l$ (adessiivi lõpp) ja - $i$ (mitmus või minevik). Rõõmulauseid eristab markeri -id (mitmuse osastav või minevik) suhteline rohkus. Pelgalt morfoloogiliste markerite äratundmise ja nende statistilise jaotuvuse põhjal on väga raske sõnastada AET-le juhist selle kohta, mida järeldada näiteks konkreetses lauses ette tuleva mitmuse nominatiivi tunnuse - $d$ põhjal. On siiski ligi kaks korda suurem tõenäosus, et lause viitab mõnele aktiivsemale emotsioonile (rõõm, viha) ja poole väiksem tõenäosus, et ta viitab kurbusele, kuid välistada ei saa ka neutraalsust.

\subsection{Sõnavara}

Uuritud 361 lauses kasutati kokku 3134 sõnet, neist 1545 erinevat. Keskmiselt tuli iga sõne andmebaasis seega esile 2 korda, kuid reaalsus on see, et suurem osa (76\%) sõnesid esines vaid ühekordselt. Sõnesid, mis tulid materjalis esile 2 või enam korda, oli 369. Materjal on ilmselgelt liiga väike, et teha paikapidavaid statistilisi järeldusi igale emotsioonile iseloomuliku korduva sõnavara kohta. Eriti arvestades asjaolu, et sagedusloetelude tipus esinevad sõnad, mis on eesti keeles üldiselt sagedama esiletulekuga ja seega vaevalt on kõnekad lause emotsionaalse eriväärtuse seisukohast. Kõnekam on see osa sõnavarast, mis tuleb esile ainult teatud kindla emotsiooniga lausetes ja mitte mujal. Nagu kirjanduse ülevaatest selgus, tasub teiste uurijate kogemusi arvestades pöörata eritähelepanu ühest küljest nn emotsionaalsetele võtmesõnadele (milleks on otsesed emotsiooni- ja tundenimetused, nagu viha, rõõm, kurbus, vt lähemalt Vainik 2002) ja teisest küljest nn leksikaalse külgetõmbega sõnadele (sõnad, millega antud kultuuris kaasneb kas positiivne või negatiivne emotsioon või konnotatsioon, nagu vähk või majanduskrïs). 


\subsubsection{Võtmesõnad}

Sõnu, mida annaks kvalifitseerida otseste emotsiooninimetuste hulka, tuli materjalis esile 55. Eeldades, et ühes lauses ei olnud mitut emotsiooninimetust, teeb see emotsioonidele otse (mõisteliselt) viitavate lausete osakaaluks kõigest umbes 14\%. Tegelikkuses on aga selliste lausete osakaal veel väiksem, kuna siiski leidus lauseid, mis kasutasid mitut otsest emotsioonisõna, nt Kui enne suhtusin sinusse heatahtlikultja usaldusega, siis sinu avaliku valetamise tõttu suhtun sinusse nüüd umbusu ja ükskõiksusega. Mind väsitab moodne kohustus olla ikka ja alati roosa ning rõõmus. Mõlemaid näiteid peeti vihalauseteks.

Lauses sisalduva emotsiooninimetuse põhjal ei saa kummati mitmelgi juhul üks-üheselt järeldada selle lause enda emotsiooni. Näiteks mainiti kurbuselausetes ka positiivseid emotsioonsõnu nagu armastama ja hoolima, tõsi küll, eitavas kõnes. Kurbust ennast mainiti aga ainult ühes lauses. Lisaks mainiti ka pettumust, viha, süüd, nördimust, löödud olemist ning mitmel eri viisil hirmu (kartma, õudne, verb julgema eitavas kõneviisis). Rõõmulausetes mainiti samuti rõõmu vaid ühel korral, see-eest korduvalt mainiti õnne (õnnelik) ja armastust (armas, armastama). Mainiti ka meeldimist, tänulikkust, rahulolu ja üllatust. Vihalausetes mainiti viha kahel korral, selle kõrval aga ka pettumust, imestust, muretsemist, umbusku, väsimust, ärritust, õudu. Positiivsetest emotsioonisõnadest tulid vihalausetes esile rõõm ja usaldus (vt ülal esitatud näiteid).

Tähelepanuväärne on, et otsest emotsiooninimetust sisaldanud lausete hulgas oli väga vähe neutraalseid lauseid (kokku 3). See tähendab seda, et otsene emotsiooninimetus ennustab suure tõenäosusega lause neutraalsest erinevat kvaliteeti. Kahtlemata on see hea uudis AET-le, kuna saab sõnastada selge tendentsi: kui lause sisaldab mõnda otsestest emotsiooninimetustest, on neutraalsus vähe tõenäoline. Seega peaks AET osaks kindlasti olema eestikeelsete emotsiooni-ja tundenimetuste loend. Sellest loendist üksi jääb aga kindlasti väheks, kuna tervelt 83\% emotsioonilausetest, mis katseisikute poolt olid piisava kindlusega määratud, ei sisaldanud mingit sellekohast otsest viidet. Suurem osa teksti põhjal määratud emotsioonidest väljendus kuidagi teisiti kui otsese emotsiooninimetusega.

Veel üks võimalik nn võtmesõnade rühm on emotsioonidega seotud semantiliselt, keelekasutaja tavateadmiste kaudu. Need on sõnad, mis kirjeldavad või nimetavad emotsioonide nn väljendusliigutusi (nt naeratus, pisarad, näkku irvitama, aplaus, ovatsioonid), füüsilist väljaelamist (peksma, möllama) või verbaalset väljaelamist (hüüatama, käratama, sõimama). Selliseid sõnu sisaldavate deskriptiivsete lausete osakaal oli materjalis suurim rõõmu puhul (10,7 lauset saja kohta), viha ja kurbuse puhul vähe (vastavalt 3,8 ja 2,6). Ka selliste väljendite loend peaks kuuluma AET koosseisu.

Võtmesõnadeks võiks olla ka kinnistunud piltlikud emotsioonikirjeldused, kuid neid tuli uuritavas materjalis esile väga vähe (nt Hing kargas täis! (viha); Ja Mu hing läks katki..., Ma läksin liimist lahti... (kurbus)), kuid kahtlemata tuleks needki AET jaoks loenditena esitada. Mida aga esitada ei saa, ja mis jääbki ilmselt peavalu valmistama, on uudisloominguline piltlikkus, nt Nagu oleks Eestisse jäänud üks suur auk, kuhu on koos Juhaniga langenud suur osa meie inimlikkusest (kurbus). 


\subsubsection{Leksikaalne külgetõmme}

Üks strateegia, mida katses osalenud isikud nähtavasti kasutasid emotsioonide omistamisel lausetele, kus puudusid otsesed emotsiooninimetused või vihjed emotsioonide väljendustegevusele, oli emotsiooni järeldamine lauses sisalduva hinnangulisuse põhjal. Nagu kirjanduses osutatud, on hinnangut mitmesugust, ning osa sellest on tihedasti seotud lausele omistatava emotsiooniga (Bednarek 2009). Joonisel 4 on näha hinnangut sisaldavate lausete distributsioon aineses. Kuivõrd hinnangut esines ka neutraalsetes lausetes, ei ole ka see üksi võetuna piisavaks emotsioone eristavaks kriteeriumiks. AET-l on kindlasti oluline arvestada ka hinnangu valentsi, kuna siin ilmneb kindlasuunaline tendents, mis on näha ka joonisel 4: negatiivset hinnangut sisaldav lause ei ole väga tõenäoliselt rõõmus ning positiivset hinnangut sisaldav lause ei ole suure tõenäosusega vihane ega kurb.

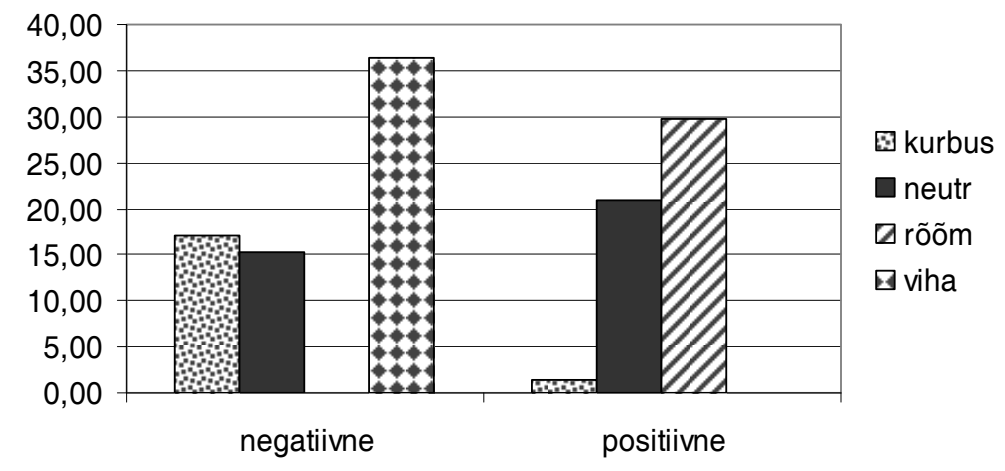

Joonis 4. Hinnangu distributsioon lausetüüpides (arv 100 lause kohta)

Leksika, mille järgi hinnangut tekstis potentsiaalselt võiks ära tunda, on mitmekesine ja vajab kahtlemata veel põhjalikumat läbiuurimist. Olgu siinkohal vaid loetletud ja näitlikustatud mõningad ainestikus esinenud võimalused. Näiteks negatiivset hinnangut implitseerivad adjektiivid nagu haige, halb, kalk, lootusetu, arusaamatu, keeruline, raske, segane, kahtlane, kättesaamatu, küündimatu, labane, laisk, müüdav, naeruväärne, oskamatu, paks, süüdimatu, rumal, tobe, õudne. Positiivset hinnangut implitseerivad hea, suurepärane, loomulik, perekeskne, rahulik, suursugune, tasakaalukas, vajalik, huvitav, fantastiline, õige, elujõuline, geniaalne, ligitõmbav, professionaalne, täiuslik, tore, uhiuus. Substantiividest kalduvad endaga siduma negatiivset hinnanguväärtust nt hilp, punt, lapsikus, kiusamine, valetaja, vastutamatus, mõttelaiskus, kriis, majanduskrahh ja lisaks rodu poliitikaga seonduvat sõnavara: minister, president, poliitik, rïgiasutus, rïk, valitsus, alkoholipïrang, hinnatõus, kommunismikuritegu. Positiivne hinnanguväärtus võib kaasneda sõnadega nagu arukus, soojus, avarus, sõber, sõbranna, lapsepõlvesõber, soojendamine, privileeg, armumine, kingitus. Esile tulnud verbidest sisaldavad negatiivset hinnangulist komponenti nt liialdama, katkema, korrumpeeruma, juhtuma, kulutama, passima, peksma, trügima, tuhnima, valetama; positiivset võitma, tasakaalustama, mõtestama, mõistma, väärima, meeldima.

Tundub mõistlik, et AET oskaks arvesse võtta lause hinnangulisusest sugenevat võimalust emotsionaalseks interpretatsiooniks. Selleks tuleb moodustada 
hinnanguliste kõrval- ja põhitähendustega sõnade loend, milleks mõningat abi pakub kindlasti Piret Volli eesti keele konnotatiivseid aspekte käsitlev magistritöö (2002). Lisaks tuleb hinnanguliste adjektiivide ja verbide leidmiseks süstemaatiliselt läbi töötada sõnastikud, ning võimalik, et korraldada ka katseid. See on kindlasti üks AET loomise ressursinõudlikumaid etappe. Lihtne ei saa lause hinnanguväärtuse määramise ja sellest emotsiooni järeldamise õpetamine arvutile küll sellegipoolest kindlasti olema. Esiteks juba eituse võimaliku mõju tõttu ning teiseks ka selle tõttu, et komplekssete lausete eri osades võidakse kõrvutada või vastandada eri hinnanguväärtustega nähtusi, mille mehaaniline kalkuleerimine ei pruugi anda adekvaatset tulemust.

\subsection{Ekspressiivsus}

Üks raskesti mõõdetav tunnus, mis emotsionaalseid lauseid neutraalsetest ilmselt eristab ja mille järgi katseisikud arvatavasti intuitiivselt otsuseid langetasid, on ekspressiivsus ehk väljenduslikkus. Ekspressiivse lausungi puhul on aru saada, et see väljendab lausungi autori enda samal hetkel kogetavat emotsiooni. Ekspressiivset lausungit võib iseloomustada lühidus, hüüdelisus, retoorilised küsimused, direktiivsus, ütte kasutamine, polaarsed adjektiivid, intensiivistavad adverbid, kordus, hüüdsõnad, vande- või kirumissõnad, kinnisvormelid, deminutiivid, pejoratiivid, piltlik keelekasutus (Foolen 1997). Näiteid ainestikus esinenud rõõmsatest ekspressiividest: Suur tänu kõikidele häälekatele fännidele! Kõik ei ole veel kadunud, sõbrad! Ja milline publik! Ilus! Hea Kadri, ma soovin, et Sul elus hästi läheks! Kurbust väljendavad nt See oli nii suur kaotus! Ma ei tunne, et minust midagi sõltuks. Ma ei tea, kuidas edasi... ning viha: Absurd! Sotti ei saa! Paluks mitte ühtegi piiksu kriisistja katastroofist! No saage aru! No mis sa tahad nendest naistest saada?! Nii ju ei lähe! Nagu öeldakse, ei au ei häbi! Kus on nüüd politsei?! Aitab!

Saja lause kohta oli ekspressiivseid kurbuse puhul umbes 9, rõõmu puhul 8,3 ja viha puhul 18,6. Seega ei kujuta ekspressiivsus endast kaugeltki emotsioonilause vältimatut tunnust. Teisest küljest on ekspressiivsete lausungite äratundmine süntesaatori jaoks üks kõige olulisemaid ülesandeid, kuna just siin on vaja rakendada tavalisest erinevat intonatsiooniregistrit. Arvatavasti on suhteliselt raske arvutile selgeks teha kõiki ekspressiivsuse kriteeriume, kuna selles vallas on vahendite repertuaar väga mitmekesine. Loetletud tunnustest on lühidus, hüüu- ja küsimärgid kergesti leitavad, samuti ilmselt üte. Interjektsioonid moodustavad suletud sõnaklassi ja neidki saab AET-le nimekirjana ette anda. Samuti on mõeldav koostada piltlike ja kinnisväljendite loendid. Samas on ebaselge, kuidas õpetada eristama arvutit retoorilist küsimust harilikust või retoorilist direktiivi tavalisest käsust-keelust. 


\section{Kokkuvõte ja arutelu}

Kuidas siis õpetada arvutile empaatiat, kuidas õpetada teda üksnes kirjaliku lause põhjal selle võimalikku emotsiooni ära tundma? Üks on selge - arvuti ei ole inimene, ta ei saa ennast samastada lause autori või protagonisti seisukorraga ja ta ei loe midagi oma multimodaalsele kogemusele tuginedes välja n-ö "ridade vahelt" (vrd Marmolejo-Ramos jt 2009). Arvutil tuleb lähtuda palju pealiskaudsematest tunnustest, ta saab otsida ja tuvastada ainult seda, mis on kirjas digitaalsetel märgiridadel.

Käesolevas artiklis sai läbi arutatud tähtsamad teoreetilised seisukohad ja mujal tehtud tekstianalüüsimeetodite sobivus eeskujudena. Mida on sellest ülevaatest kõrva taha panna arvutile empaatia õpetamise tarbeks? Põhimõtteliselt on emotsiooni kaasnemine lausega alati võimalik, kuivõrd lause kujutab endast lausuja eneseväljendust. Samas ei saa öelda, et see oleks nii alati ja enesestmõistetavalt. Normaalne, vaimselt terve inimene kogeb ja väljendab (tugevaid) emotsioone vastavalt situatsioonile ainult aeg-ajalt ja sedasama peaks tegema ka "empaatiline" kõnesüntesaator. Arvutigi peaks esiteks oskama eristada neutraalset teksti emotsionaalsest ja teiseks tegema vahet olulisematel kirjas kajastuvatel emotsioonidel. Teiseks oleneb teksti ja selles sisalduvate lausete emotsionaalsuse määr kindlasti žanrist. Douglas Biber ja Edward Finegan leidsid ulatusliku tekstikorpuse (500 teksti) läbisõelumise tagajärjel, et ainult 3\% uuritud ingliskeelsetest tekstidest sisaldasid märkimisväärselt afektile viitavat sõnavara (adverbid, adjektiivid ja verbid). Kõige enam viidati seejuures emotsioonidele isiklikes kirjades (Biber, Finegan 1989). Käesoleva artikli autori meelest ei saa seetõttu eeldada, et mistahes eestikeelset teksti žanrist olenemata iseloomustaks leksikaalselt markeeritud emotsionaalsus. Usutavasti on ka eesti keele puhul emotsioonide väljendamine mõnes tekstiliigis ootuspärasem kui teistes. Emotsioonituvastus ja žanrianalüüs võiksid tulevikus üksteist vastastikku hõlbustada.

Kindlasti on kasulik olla kursis meetoditega, mida teiste keelte puhul on emotsioonide või hinnangute tuvastamisel rakendatud, kuid otse ülevõtmiseks sobivat eeskuju kirjandusest siiski praegu veel ei leidunud. Seda eeskätt selle tõttu, et eesti tulevase emotsioonituvastaja eesmärk ei ole mingi üldotstarbeline teksti meeleolu või valentsi analüüs, vaid et ta peab suutma määrata konkreetse lause emotsiooni ja seda üsna täpselt piiritletud kategooriate terminites. Teiseks on selge, et mis puudutab emotsioonidega seotud sõnade ja võimalike konstruktsioonide loendeid, siis tuleb need eesti keele jaoks algusest peale ise luua vastavalt sellele sõnavarale ja lokaalsele grammatikale, mida eestikeelsetes emotsioonilausetes kasutatakse.

Läbi sai kaalutud ka inimeste poolt piisava üksmeelega ära tuntud emotsioonilausete mitmete formaalsete ja sisulisemate tunnuste kasutatavus automaatses emotsioonituvastuses. Artikli lisana esitatakse veel kord kokkuvõtlikult need tendentsid, mis andmekaeve tulemusena õnnestus empiirilise materjali analüüsil välja selgitada. Osa tendentsidest väljendavad positiivseid seoseid nähtuste vahel (kui A, siis tõenäoliselt B), osa negatiivseid (kui A, siis pigem mitte B). Ükski neist tendentsidest ei ole siiski reegli kindlusega, nad saavad anda üksnes osalise panuse tulevase AET töösse. Ilmselt peabki AET hakkama rehkendama mitmete võimalike lauses leitavate mingi emotsiooni tõenäosust suurendavate ja vähendavate tunnuste koosmõju. 
AET loomise seisukohast on kindlasti tähtis ka kasutatavate kriteeriumide ressursinõudlikkus. Mida sisulisem kriteerium, seda ressursinõudlikum. Suhteliselt lihtne on panna arvuti vaatama lauselõpumärke või arvutama lause pikkust sõnedes või tähekohtades. Tunduvalt töömahukam seevastu on morfoloogiline analüüs (koos ühestamisega) ning leksika võrdlemine emotsioonide suhtes relevantsete sõnade sõnastikuga, mida praeguse seisuga eesti keele jaoks ei ole veel olemaski. Eesti keele afektisõnastik tuleb selle keeletehnoloogilise rakenduse tarbeks alles spetsiaalselt luua. Ideed selle kohta, kust peale hakata ja kuidas kasutada olemasolevaid eesti keele ressursse ning tehtud uuringuid, on olemas, kuid selle kõige järeleproovimine ning kirjeldamine nõuab palju tööd ning on kahtlemata juba uue artikli teema. AET võiks rakendada lausest otsitavate tunnuste hierarhiat: esmalt otsida "odavamaid" tunnuseid ja alles siis, kui neist ei piisa, vaagida ressursinõudlike tunnuste olemasolu või puudumist.

Nagu välja tuli, kujutas emotsiooni määramine ilma kontekstita esitatud kirjaliku lause puhul endast küllaltki rasket ülesannet ka katses osalenud inimestele, kelle arvamused kippusid lahknema. Autor ei ole praeguse seisuga eriti optimistlik selle suhtes, et AET tuleks inimesest “targem”. Ilmselt nii mõnegi lause puhul ongi võimalik mitmene interpretatsioon ja päris paljude tekstis ette tulevate lausete kohta ei piisa üldse tõenäosuslikke tunnuseid mingi konkreetse emotsiooni määramiseks. On täitsa võimalik, et üksikus kirjalikus tekstilauses (eriti kui see on kontekstisidus) ei sisaldugi taustaks olevate emotsioonide kohta piisavalt märgilist infot.

Simone Schnall (2005) väidab tuginedes Sperberi ja Wilsoni relevantsusteooriale (1995), et kommunikatsioonis ei toimigi põhimõtteliselt nn "kodeerimismudel”, vaid et oluline on jagada ühist reaalsust ning teha järeldusi suhtleja kavatsuste kohta esitatud asitõendite põhjal. Kui seda seisukohta aktsepteerida, siis ei peakski AET otsima tekstist niivõrd konkreetsele emotsioonile omast koodi kui olema võimeline tegema tõenäosuslikke järeldusi asitõendite põhjal, milleks on igas konkreetses tuvastamisele tulevas lauses sisalduv info. "Empaatiline arvuti" peaks mingil määral jagama ka eestlaste ühist reaalsust (näiteks sõnastiku näol, mis talletab "üldiselt positiivsed” ja "üldiselt negatiivsed” asjad, omadused jne).

Kokkuvõttes ei ole arvutile empaatia õpetamise ülesanne võib-olla siiski päris lootusetu, kuivõrd arvuti ei pea ju tundeid päriselt jagama, vaid looma lihtsalt piisavalt usutava mulje võimest olla emotsionaalselt etteloetava teksti autori "nahas". Kõnesüntees, mille vajadustest on AET ellu kutsutud, võiks seada eesmärgiks mitte eksida lause hinnangulise valentsi ja intensiivsuse osas ja jätta emotsionaalse tõlgenduse tegemise (konkreetsete kategooriate mõttes) ja/või mittetegemise rahumeeli kuulaja teha. Kui kõnesünteesi vajadustest lähtuv emotsioonituvastaja on kord loodud, võib selle potentsiaalne rakendus olla tulevikus laiemgi. Võimalikuks saab hinnata mistahes tekstide emotsiooni ja see võib kasulikuks osutuda näiteks elektroonse kirjavahetuse, interneti e-postituste, kommentaaride jm tekstide automaatsel käsitlemisel.

\section{Viidatud kirjandus}

Al, Mostafa; Shaikh, Masum; Prendinger, Helmut; Mitsuru, Ishizuka 2007. Assessing sentiment of text by semantic dependency and contextual valence analysis. - A. Paiva, R. Prada, R. W. Picard (Eds.). Affective Computing and Intelligent Interaction. Second International Conference, ACII 2007 Lisbon, Portugal, September 12-14, 2007. Pro- 
ceedings. Lecture Notes in Computer Science, 4738. Berlin, Heidelberg: SpringerVerlag, 191-202. doi:10.1007/978-3-540-74889-2_18

Altrov, Rene 2008. Eesti emotsionaalse kõne korpus: teoreetilised toetuspunktid. - Keel ja Kirjandus, 4, 261-272.

Altrov, Rene; Pajupuu, Hille 2008. The Estonian emotional speech corpus: Release 1. - The Third Baltic Conference on Human Language Technologies. Vilnius: Vytauto Didžiojo Universitetas; Lietuviu kalbos institutas, 9-15.

Baron-Cohen, Simon; Wheelwright, Sally 2004. The empathy quotient: An investigation of adults with asperger syndrome or high functioning autism, and normal sex differences. - Journal of Autism and Developmental Disorders, 34 (2), 163-175. doi:10.1023/B:JADD.0000022607.19833.00

Bednarek, Monika 2008. Emotion Talk across Corpora. Houndmills, New York: Palgrave Macmillan.

Bednarek, Monika 2009. Dimensions of evaluation. Cognitive and linguistic perspectives. Pragmatics and Cognition, 17 (1), 146-175.

Beljanin, Valeri 2000. Osnovõ psiholingvističeskoi diagnostiki: modeli mira v literature. Moskva: Trivola.

Biber, Douglas; Finegan, Edward 1989. Styles of stance in English: Lexical and grammatical marking of evidentiality and affect. - Text, 9 (1), 93-124. doi:10.1515/ text.1.1989.9.1.93

Bracewell, David B.; Minato, Junko; Ren, Fuji; Kuroiwa, Shingo 2006. Determining the emotion of news articles. - D-S. Huang, K. Li, G. W. Irwin (Eds.). Computational Intelligence. International Conference on Intelligent Computing, ICIC 2006, Kunming, China, August 16-19, 2006. Proceedings, Part II, Vol. 2. Berlin, Heidelberg, New York: Springer, 918-923. doi:10.1007/11816171_115

Buck, Ross 1989. On the semiotics of emotion: Spontaneous and symbolic communication. - Walter A. Koch (Ed.). For a Semiotics of Emotion. Bochum: Studienverlag Dr. Norbert Brockmeyer, 1-33.

Bühler, Karl 1934. Sprachtheorie: Die Darstellungfunktion der Sprache. Stuttgart: Fischer. ConceptNet. http://conceptnet.media.mit.edu (07.12.09).

Damasio, Antonio R. 1999. The Feeling of What Happens. Body and Emotion in the Making of Consciousness. New York: Harcourt Brace \& Company.

Darwin, Charles 1998. The Expression of Emotion in Man and Animals. Introduction and Commentary by P. Ekman. Chicago: Chicago University Press.

Downes, William 2000. The language of felt experience: Emotional, evaluative and intuitive. Language and Literature, 9 (2), 99-121. doi:10.1177/096394700000900201

Eesti emotsionaalse kõne korpus. http://193.40.113.40:5000/ (07.12.09).

Foolen, Ad 1997. The expressive function of language: Towards a cognitive semantic approach. - S. Niemeier, R. Dirven (Eds.). The Language of Emotions. Conceptualization, Expression and Theoretical Foundation. Amsterdam/Philadelphia: John Benjamins Publishing Company, 15-32.

FrameNet. http://framenet.icsi.berkeley.edu/ (07.12.09).

Goleman, Daniel 2006. Social Intelligence. The New Science of Human Relationships. London: Hutchinson.

Grefenstette, Gregory; Qu, Yan; Evans, David A.; Shanahan, James G. 2006. Validating the coverage of lexical resourses for affect analysis and automatically classifying new words along semantic axes. - James G. Shanahan, Yan Qu, Janyce M. Wiebe (Eds.). Computing Attitude and Affect in Text: Theory and Applications. Dordrecht: Springer, 93-107. doi:10.1007/1-4020-4102-0_9

Hacking, Ian 1999. The Social Construction of What? Cambridge MA: Harvard University Press. 
Hunston, Susan; Thompson, Geoff 2001. Evaluation in Text. Authorical Stance and the Construction of Discourse. Oxford: Oxford University Press.

Hunston, Susan; Sinclair, John 2001. A local grammar of evaluation. - S. Hunston, G. Thompson (Eds.). Evaluation in Text. Authorical Stance and the Construction of Discourse. Oxford: Oxford University Press, 74-101.

Iida, Akemi; Campbell, Nick; Higuchi, Fumito; Yasumura, Michiaki 2003. A corpus-based speech synthesis system with emotion. - Speech Communication, 40 (1-2), 161-187. doi:10.1016/So167-6393(02)00o81-X

Kerge, Krista; Pajupuu, Hille; Tamuri, Kairi 2008. Where should TTS-synthesizer pause and breath? - The Third Baltic Conference on Human Language Technologies. Vilnius: Vytauto Didžiojo Universitetas; Lietuviu kalbos institutas, 143-149.

Kövecses, Zoltan 2006. Language, Mind and Culture. A Practical Introduction. Oxford: Oxford University Press.

Laur, Mall 1987. Eesti kõne emotsionaalseid aspekte. Käsikirjaline magistritöö Tallinna Pedagoogikaülikoolis.

Liu, Hugo; Lieberman, Henry; Selker, Ted 2003. A model of textual affect sensing using realworld knowledge. - Proceedings of the 8th International Conference on Intelligent User Interfaces, Miami, Florida, USA, 125-132.

Marmolejo-Ramos, Fernando; de Juan, Maria R. E.; Gygax, Pascal; Madden, Carol; Roa, Santiago M. 2009. Reading between the lines. The activation of background knowledge during text comprehension. - Pragmatics and Cognition, 17 (1), 77-107.

Mathieu, Yvette Y. 2006. A computational semantic lexicon of French verbs of emotion. James G. Shanahan, Yan Qu, Janyce M. Wiebe (Eds.). Computing Attitude and Affect in Text: Theory and Applications. Dordrecht: Springer, 109-124. doi:10.1007/1-4020 -4102-0_10

Mihkla, Meelis 2007. Kõne ajalise struktuuri modelleerimine eestikeelsele tekst-kõne sünteesile - Modelling the temporal structure of speech for the Estonian text-to-speech synthesis. Dissertationes linguisticae Universitatis Tartuensis, 8. Tartu: Tartu Ülikooli Kirjastus.

Mikita, Valdur 2008. Metsik lingvistika. Tallinn: Grenader.

Obrenovic, Zeljko; Garay, Nestor; López, Juan Miguel; Fajardo, Inmaculada; Cearreta, Idoia 2005. An ontology for description of emotional cues. - Jianhua Tao, Rosalind W. Picard, Tieniu Tan (Eds.). Affective Computing and Intelligent Interaction. First International Conference, ACII 2005, Beijing, China, October 22-24, 2005. Proceedings. Lecture Notes in Computer Science, 3784. Berlin Heidelberg: Springer, 505-512. doi:10.1007/11573548_65

Ochs, Elinor 1988. Culture and Language Development: Language Aquisition and Language Socialisation in a Samoan Village. Cambridge: Cambridge University Press.

Osherenko, Alexander 2008. Towards semantic affect sensing in sentences. - Proceedings of AISB 2008, 1-4.

Osherenko, Alexander; André, Elisabeth 2007. Lexical affect sensing: Are affect dictionaries necessary to analyze affect? - A. Paiva, R. Prada, R. W. Picard (Eds.). Affective Computing and Intelligent Interaction. Second International Conference, ACII 2007 Lisbon, Portugal, September 12-14, 2007. Proceedings. Lecture Notes in Computer Science, 4738. Berlin, Heidelberg: Springer-Verlag, 230-241. doi:10.1007/978-3540-74889-2_21

Picard, Rosalind W. 1997. Affective Computing. Mass.: The MIT Press.

Reilley, Judy; Seibert, Laura 2003. Language and emotion. - R. J. Davidson, K. R. Scherer, H. H. Goldsmith (Eds.). Handbook of Affective Sciences. New York: Academic Press, $535-559$.

Saareste, Andrus 1927. Tundmused tegurina keele arengus. - Eesti Keel, 7, 161-184. 
Scherer, Klaus R.; Johnstone, Tom; Klasmeyer, Gundrun 2008. Vocal expression of emotion. - M. Lewis, J. M. Haviland-Jones, L. Feldman Barrett (Eds.). Handbook of Emotions. Third ed. New York: Guilford Press, 433-456.

Schnall, Simone 2005. The pragmatics of emotion language. - Psychological Inquiry, 16, $28-31$.

Shanahan, James G.; Qu, Yan; Wiebe, Janyce M. (Eds.) 2006. Computing Attitude and Affect in Text: Theory and Applications. Dordrecht: Springer. doi:10.1007/1-4020-4102-O

Sperber, Deidre; Wilson, David 1995. Relevance: Communication and Cognition. 2nd edition. Oxford: Blackwell.

Zhang, Li 2009. Exploration of affect sensing from speech and metaphorical text. - M.Chang, Rita Kuo, Kinshuk, Gwo-Dong Chen, Michitaka Hirose (Eds.). Learning by Playing. Game-based Education System Design and Development. 4th International Conference on E-Learning and Games, Edutainment 2009, Banff, Canada, August 9-11, 2009. Proceedings. Lecture Notes in Computer Science, 5670. Berlin/Heidelberg: Springer-Verlag, 251-262. doi:10.1007/978-3-642-03364-3_31

VAAL 2000. http://www.vaal.ru/proekt/vaal2000.php (07.12.09).

Vainik, Ene 2002. Millest on tehtud eestlaste emotsioonisõnavara? - Keel ja Kirjandus, 8, 537-553.

Vainik, Ene; Velt, Anneli 2006. Viha metafoorid ja kognitiivne mudel eesti keeles. - Keel ja Kirjandus, 2, 104-122.

Ververidis, Dimitrios; Kotropoulos, Constantine 2006. Emotional speech recognition: Resources, features, and methods. - Speech Communication, 48 (9), 1162-1181. doi:10.1016/j.specom.2006.04.003

Veski, Asta 1982. Eesti keele grammatika II. Tartu.

Voll, Piret 2002. Tähenduse konnotatiivne aspekt ja selle kajastamine ükskeelses sõnaraamatus. Käsikirjaline magistritöö Tartu Ülikoolis.

Watzlawick, Paul; Bavelas, Janet B.; Jackson, Don 1967. Pragmatics of Human Communication. A Study of Interactional Patterns, Pathologies, and Paradoxes. New York: W. W. Norton \& Company.

Whissell, Cynthia M. 1989. The dictionary of affect in language. - R. Plutchik, H. Kellerman (Eds.). Emotion: Theory, Research, and Experience. New York: Academic Press, $113-131$.

Wierzbicka, A. 1999. Emotions across Languages and Cultures. Diversity and Universals. Cambridge: Cambridge University Press. doi:10.1017/CBO9780511521256

Wilce, James M. 2009. Language and Emotion. New York: Cambridge University Press.

Wilson, Theresa; Wiebe, Janyce; Hoffmann, Paul 2005. Recognizing contextual polarity in phrase-level sentiment analysis. - Proceedings of the Conference on Human Language Technology and Empirical Methods in Natural Language Processing, Vancouver, British Columbia, Canada, 347-354.

WordNet. http://wordnet.princeton.edu/ (07.12.09).

$\mathrm{Wu}$, Chung-Hsien; Chuang, Ze-Jing; Lin, Yu-Chung 2006. Emotion recognition from text using semantic labels and separable mixture models. - ACM Transactions on Asian Language Information Processing, 5 (2), 165-182. doi:10.1145/1165255.1165259

Yan, Jiajun; Bracewell, David B.; Ren, Fuji; Kuroiwa, Shingo 2008. The creation of a Chinese emotion ontology based on HowNet. - Engineering Letters, 16 (1), 166-171.

Ene Vainiku (Eesti Keele Instituut) uurimisobjektiks on eesti keele emotsioonisõnavara, selle struktuur, semantika ja varieerumine. Huvipakkuvateks teemadeks on ka psühholingvistika, kognitiivne semantika ja keele ning emotsioonide interaktsioon laiemalt.

Ene.Vainik@eki.ee 
Lisa. Tunnuste ja emotsioonide seostumise tendentsid

\begin{tabular}{|c|c|c|}
\hline Kategooria & Tunnus (selgitus) & Emotsioon \\
\hline \multirow{4}{*}{ lõpumärgistus } & (Iõpumärk ei ole:) üksik punkt & vaevu neutraalne \\
\hline & (lõpumärk on:) ? / ! / ?! & pigem viha \\
\hline & (Iõpumärk on:)! & pigem rõõm \\
\hline & ((lõpu)märk on:) ... & pigem kurbus \\
\hline eitav kõne & (lauses sisaldub:) ei/mitte/pole/polnud/polegi & pigem negatiivne \\
\hline jaatav kõne & (lauses ei sisaldu:) ei/mitte/pole/polnud/polegi & pigem neutraalne/rõõm \\
\hline $\begin{array}{l}\text { sõnede pikkus } \\
\text { tähemärkides }\end{array}$ & $\begin{array}{l}\text { lühikeste sõnede (kuni } 4 \text { tähemärki) osakaal lauses } \\
\text { suurem kui pikkadel }\end{array}$ & pigem kurbus \\
\hline \multirow{6}{*}{$\begin{array}{l}\text { lause esimese } \\
\text { sõna liik }\end{array}$} & \multirow{2}{*}{ adverb } & pigem viha \\
\hline & & vaevu rõõm \\
\hline & \multirow{2}{*}{ pronoomen (eriti I isik) } & pigem kurbus \\
\hline & & vaevu viha \\
\hline & adjektiiv & pigem rõõm \\
\hline & sidesõna & vaevu neutraalne \\
\hline \multirow{3}{*}{$\begin{array}{l}\text { sõnaliigid } \\
\text { läbivalt }\end{array}$} & adverbe kaks või rohkem & pigem negatiivne \\
\hline & adverbe üks või vähem & pigem neutraalne/rõõm \\
\hline & substantiive üks või vähem & pigem kurbus \\
\hline $\begin{array}{l}\text { morfoloogiline } \\
\text { marker }\end{array}$ & $-d$ & pigem viha/rõõm \\
\hline \multirow{2}{*}{ nn võtmesõna } & otsene emotsiooninimetus & vaevu neutraalne \\
\hline & emotsioonide väljenduse kirjeldus & vaevu neutraalne \\
\hline \multirow{2}{*}{$\begin{array}{l}\text { nn leksikaalne } \\
\text { külgetõmme }\end{array}$} & negatiivne hinnang & vaevu rõõm \\
\hline & positiivne hinnang & vaevu viha/kurbus \\
\hline
\end{tabular}




\section{HOW TO TEACH EMPATHY TO A SPEECH SYNTHESIZER? ON THE POSSIBILITY OF IDENTIFYING EMOTION SOLELY FROM WRITTEN ESTONIAN SENTENCES}

\section{Ene Vainik}

Institute of the Estonian Language

There is a growing need for more naturalness in synthetic Estonian speech. One of the measures to be taken is to teach the computer to apply differentiated acoustic registers according to the different emotions (joy, sadness, anger) or neutrality of the text. The present article deals with how to detect the quality of emotion vs. neutrality relying solely on the information present in the Estonian written text.

The first part of the article provides a theoretical overview of how, in principle, emotions can be expressed in speech. Besides the ideational/referentional mode (i.e. the use of a literal emotion term, like sadness) there is a variety of linguistic cues of expressiveness to be detected. As a result of an overview of the literature on sentiment analysis and affective computing it is stated that the approaches vary in many respects. First, there is a variation in what is considered to be the unit of analysis in the first place (text, passage, sentence, or clause). Secondly, what exactly is being looked for: particular emotions in terms of specific categories (e.g. fear, joy, sadness, anger etc.) or more abstract dimensions (e.g. valence, intensity). The third aspect to be noticed is whether the authorial or also non-authorial affect is taken into account. Most of the approaches exploit lexical features and compare the items present in the text with an affective lexicon.

In the empirical part of the study the results of a statistical analysis of Estonian sentences (altogether 361) are presented. The sentences were retrieved from the Estonian Emotional Speech Corpus, where 55 test subjects had evaluated their emotion (joy, sadness, anger) or neutrality. To put the results very briefly is to say that identifiying the emotion of a sentence entirely out of context must have been a pretty demanding task. There was not much congruence in the evaluations. Looking for the features which could work for the computer as cues for automatic emotion detection ended up in a list of probabilistic tendencies. Features such as punctuation, length of sentence (in characters), part of speech of the first word, negation etc. were used. Also the main lexical means and some strategies of attributing emotion according to the evaluative value of the sentence were described in some detail.

The article ends with a conclusion that enabling a speech synthesizer to imitate human emotions can be compared with modeling human empathy. This is not an easy task. None of the systems created for other languages can be simply adapted for Estonian. This is firstly because emotions and their expressions are culturespecific to some extent and, secondly, because the Emotion Detector should rely on an Estonian affect dictionary, which does not exist, yet. Consequently, there is still a lot to do in the field.

Keywords: emotions, written text, speech synthesis, sentiment analysis, affective computing, Estonian 